\title{
Microwave effects in Drosophila melanogaster
}

\author{
M. DARDAlhoN $(*)$, A. J. BerteAud $\left({ }^{* *}\right)$ and D. AVErbeCK $(*)$ \\ (Manuscrit reçu le 23 mars 1979)
}

\begin{abstract}
Experiments were set up to investigate the effects of open space microwave irradiation of the millimeter $(73 \mathrm{GHz})$ and the centimeter $(17 \mathrm{GHz})$ range in Drosophila melanogaster. We used the wild type strain Paris and the strain $\delta$ carrying melanitic tumors in the 3rd larval stage, in the pupae and the adults. The power densities were up to $100 \mathrm{~mW} \cdot \mathrm{cm}^{-2}$ for $73 \mathrm{GHz}$ and about $60 \mathrm{~mW} \cdot \mathrm{cm}^{-2}$ for microwaves at $17 \mathrm{GHz}$. After $2 \mathrm{~h}$ exposure to microwaves of $17 \mathrm{GHz}$ or $73 \mathrm{GHz}$ the hatching of the irradiated eggs and their development were normal. In a few cases there was a tendency towards a diminution of the survival of eggs treated at different stages, of larvae treated in the stages 1,2 and 3 and of treated pupae. However, this was not always statistically significant. The microwave treatment did not induce teratological changes in the adults. A statistical analysis brought about slight diminutions in the incidence and multiplicity of tumors in adult flies. When wild type females were exposed to microwaves of $17 \mathrm{GHz}$ for 16 or $21 \mathrm{~h}$ and crossed with untreated males we observed a marked increase in fertility as compared to untreated samples. The viability and tumor incidence in the offspring was not affected. Similar results were obtained when microwaves treated males were crossed with untreated females.
\end{abstract}

\section{RÉSUMÉ}

Des expériences ont été faites pour étudier les effets de l'irradiation en espace libre par microondes de Drosophila Melanogaster, à l'échelle millimétrique $(73 \mathrm{GHz})$ et centimétrique $(17 \mathrm{GHz})$. Nous avons utilisé la souche Paris de type sauvage et la souche $\delta$ comportant des tumeurs mélaniques chez la larve, au $3^{\circ}$ stade de développement, chez la pupe et chez les adultes. Les densités de puissance peuvent atteindre $100 \mathrm{~mW} \cdot \mathrm{cm}^{-2}$ pour $73 \mathrm{GHz}$, et $60 \mathrm{~mW} \cdot \mathrm{cm}^{-2}$ pour $17 \mathrm{GHz}$. Après $2 \mathrm{~h}$ d'exposition aux microondes à $17 \mathrm{GHz}$ ou à $73 \mathrm{GHz}$, l'éclosion des œufs et leur développement sont normaux. Dans quelques cas, on observe une tendance à une diminution de survie des œufs traités à différentes étapes, des larves traitées aux stades 1,2 et 3 et des pupes également traitées. Toutefois, ce résultat n'est pas statistiquement significatif. Le traitement par microondes n'induit aucune altération tératologique chez les

(*) Institut Curie, Section de Biologie, 26, rue d’Ulm, 75005 Paris, France.

(**) C.N.R.S., Groupe de Recherche ${ }^{\circ} 35,2$, rue Henry Dunant, 94320 Thiais, France.

RADIOPROTECTION. VOL. 14 - 0033-8451/1979/145/\$ 4.00/C Bordas-Dunod. 
adultes. Une analyse statistique montre une faible diminution de l'apparition et de la multiplicité des tumeurs chez les mouches adultes. Lorsque des femelles de type sauvage, exposées aux microondes à $17 \mathrm{GHz}$ pendant 16 à $21 \mathrm{~h}$, sont croisées avec des mâles non traités, on observe une augmentation sensible de la fertilité par rapport à celle des témoins. La viabilité et l'apparition de tumeurs chez les descendants ne sont pas modifiées. Des résultats analogues ont été obtenus lorsque des mâles irradiés aux microondes ont été croisés avec des femelles non irradiées.

\section{INTRODUCTION}

The widespread use of microwaves in the environment makes it necessary to collect more data on their biological effects in view of the evaluation of possible biological risks. Investigations on microwave action using insects have already been useful in this respect. Recent data demonstrate the appearance of teratological changes in the darkling beetle Tenebrio molitor after treatment with low power microwaves in the waveguide [1, 2]. Another study with microwaves in the millimeter range provided no evidence for an induction of lethal effects or malformations in Drosophila melanogaster; however, changes in fertility were observed depending on the exposure time and the microwave frequency $[3,4]$.

We investigated in Drosophila melanogaster the effects of open space irradiation using microwaves of the millimeter $(73 \mathrm{GHz})$ and the centimeter $(17 \mathrm{GHz})$ range. We used microwaves of $73 \mathrm{GHz}$ since they were already shown to interfere with bacterial growth [5]. Drosophila was chosen because its genetics and developmental behaviour is well known.

\section{MATERIALS AND METHODS}

\section{Drosophila STRAINS AND CULTURE CONDITIONS}

We used the wild type strain Paris [6] and the strain $\delta$ of Drosophila melanogaster. The latter strain is known for the spontaneous development of melanitic tumors during normal growth [7].

Culture conditions have been previously described [8]. The nutrient medium consisted of cooked baker's yeast. Growth was allowed in an incubator at $23^{\circ} \mathrm{C}$ without humidity control.

\section{MiCROWAVE TREATMENT}

The microwave apparatus (Fig. 1) included either a klystron of the Varian VE 2103 type adjustable for the frequencies 69.5 to $75 \mathrm{GHz}$ (millimeter waves) or a klystron Sperry Rand SR 4419 type adjusted for the frequency of $17 \mathrm{GHz}$ (centimeter waves). The level of incident and reflected power was controlled by means of 10 or $20 \mathrm{~dB}$ couplers. Irradiations were done in free space (not in the waveguide) with or without a horn antenna, at 73 and $17 \mathrm{GHz}$ respectively. The power densities in the irradiation plane were either measured by a NARDA power meter or calculated from the power measured at the waveguide 
outlet in a matched load. Precision variable attenuators allowed a continuous variation of the power density up to $100 \mathrm{~mW} \cdot \mathrm{cm}^{-2}$ for $73 \mathrm{GHz}$ microwaves and $60 \mathrm{~mW} . \mathrm{cm}^{-2}$ for $17 \mathrm{GHz}$ microwaves.

Drosophila eggs or pupae were positioned on a small layer of nutrient medium the surface of which corresponded to the waveguide opening. The distance of the waveguide outlet and the sample was $5 \mathrm{~mm}$ for $17 \mathrm{GHz}$ and $1-2 \mathrm{~mm}$ for $73 \mathrm{GHz}$. The larvae and adults were kept in a plastic box $(10 \times 10 \times 18 \mathrm{~mm})$ with small holes to allow respiration and with an inside layer of nutrient medium for feeding.

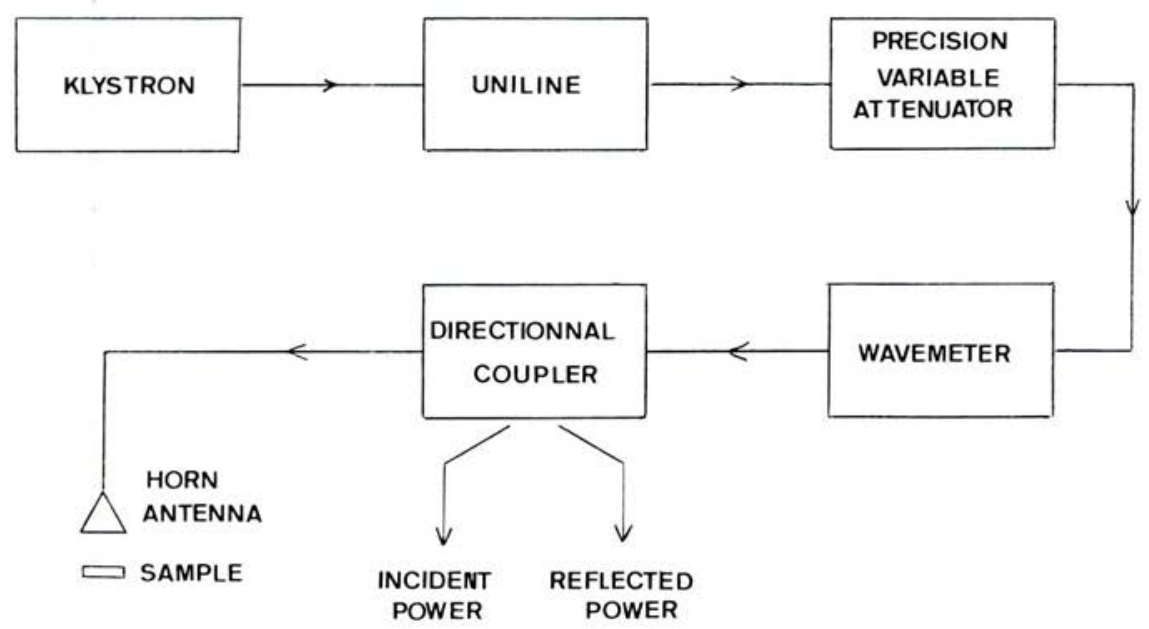

FIG. 1. - Block diagram of the microwave irradiation apparatus.

Drosophila eggs were treated in different stages of the embryonic development, i. e. 2, 4 or $5 \mathrm{~h}$ after egg laying. Their age was determined with an accuracy of \pm half an hour. The eggs were deposited on a layer of nutrient medium in an open plastic dish and exposed to microwave; for 2 or $3 \mathrm{~h}$. A control sample was kept aside under similar conditions but shielded against microwaves. In treated and control samples we determined the number of eggs which developped, which failed to develop and which were lethal, the number of pupae formed, the number of adults and the sex ratio. The results for each condition are presented in the tables as averages of at least 2 independent experiments.

The larvae were treated at stage $1,24-48 \mathrm{~h}$ old, at stage $2,48-72 \mathrm{~h}$ old or at stage 3, 72-120 h old. One sample was treated with microwaves during $3 \mathrm{~h}$, another sample kept as a control. In each sample we determined the number of developing pupae, the number of adults and the sex ratio.

Similarly to the eggs, pupae of the 1st or 2nd day were exposed to microwaves for $2 \mathrm{~h}$ on a layer of nutrient medium. Controls were kept in comparable conditions. The number of developing adults and the sex ratio were measured.

Using males and females flies of the Paris strain, we studied the effects of prolonged microwave treatments ( $16 \mathrm{~h}$ exposure, $17 \mathrm{GHz}, 60 \mathrm{~mW} . \mathrm{cm}^{-2}$ ) on fertility and development of derived eggs up to the adult stage. Five 3-day old females were treated and subsequently mated with 10 untreated males which had reach maturity for 3 days. Males and females

vOL. $14-\mathrm{N}^{\circ} 3$ 


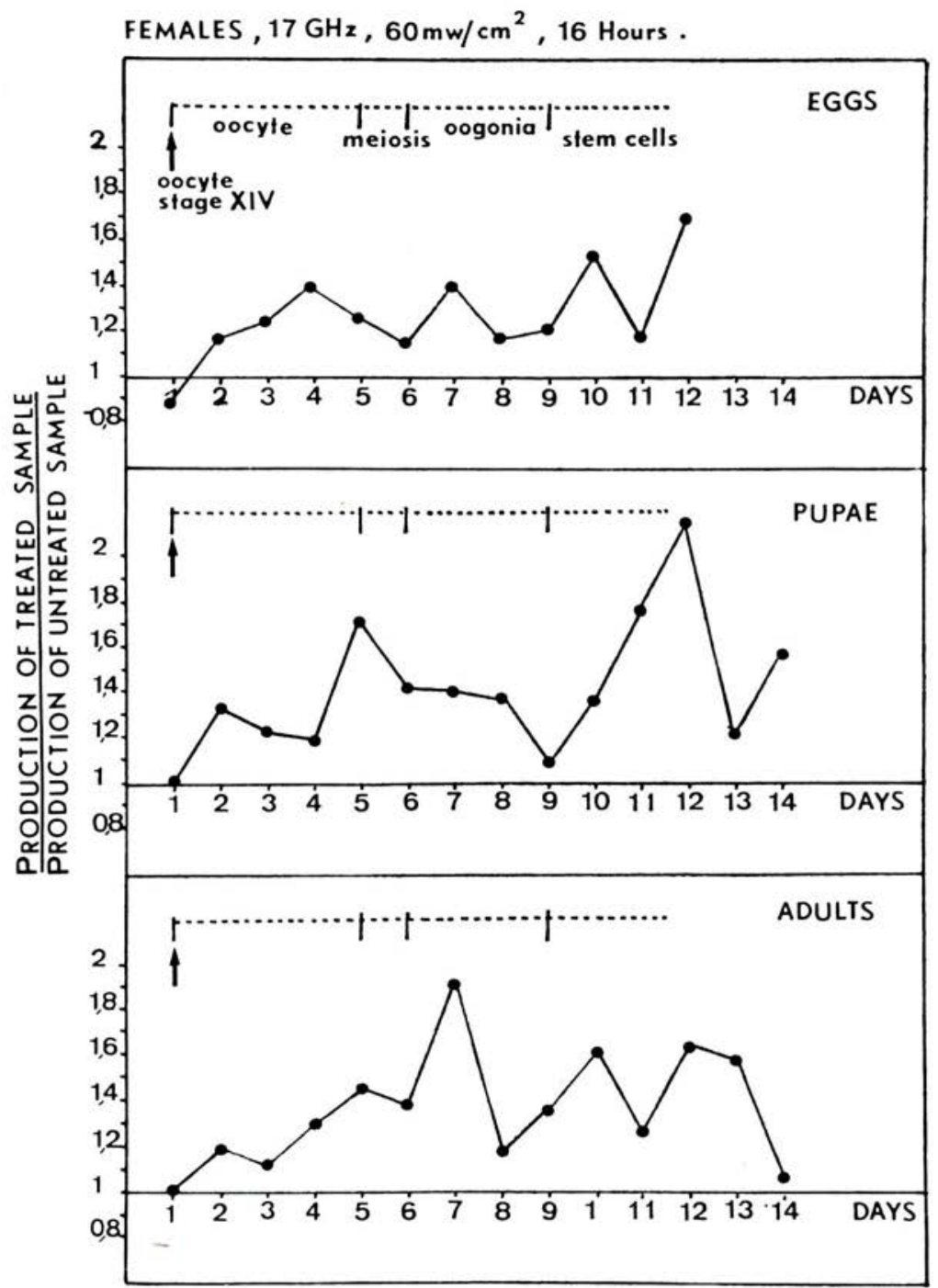

FIG. 2. - Fertility changes in females of Drosophila treated with microwaves of $17 \mathrm{GHz}$ at $60 \mathrm{~mW} \cdot \mathrm{cm}^{-2}$ for $16 \mathrm{~h}$ and mated with untreated males. The number of eggs produced per day and the number of derived pupae and adults was determined until 12-14 days. Data are given as an average of 3 independent experiments.

were transferred into tubes containing fresh medium every $24 \mathrm{~h}$ during 14 days, the daily production of eggs was determined during this period and their development followed until the adult stage. The results are presented in Figure 2 as averages of 4 independent 


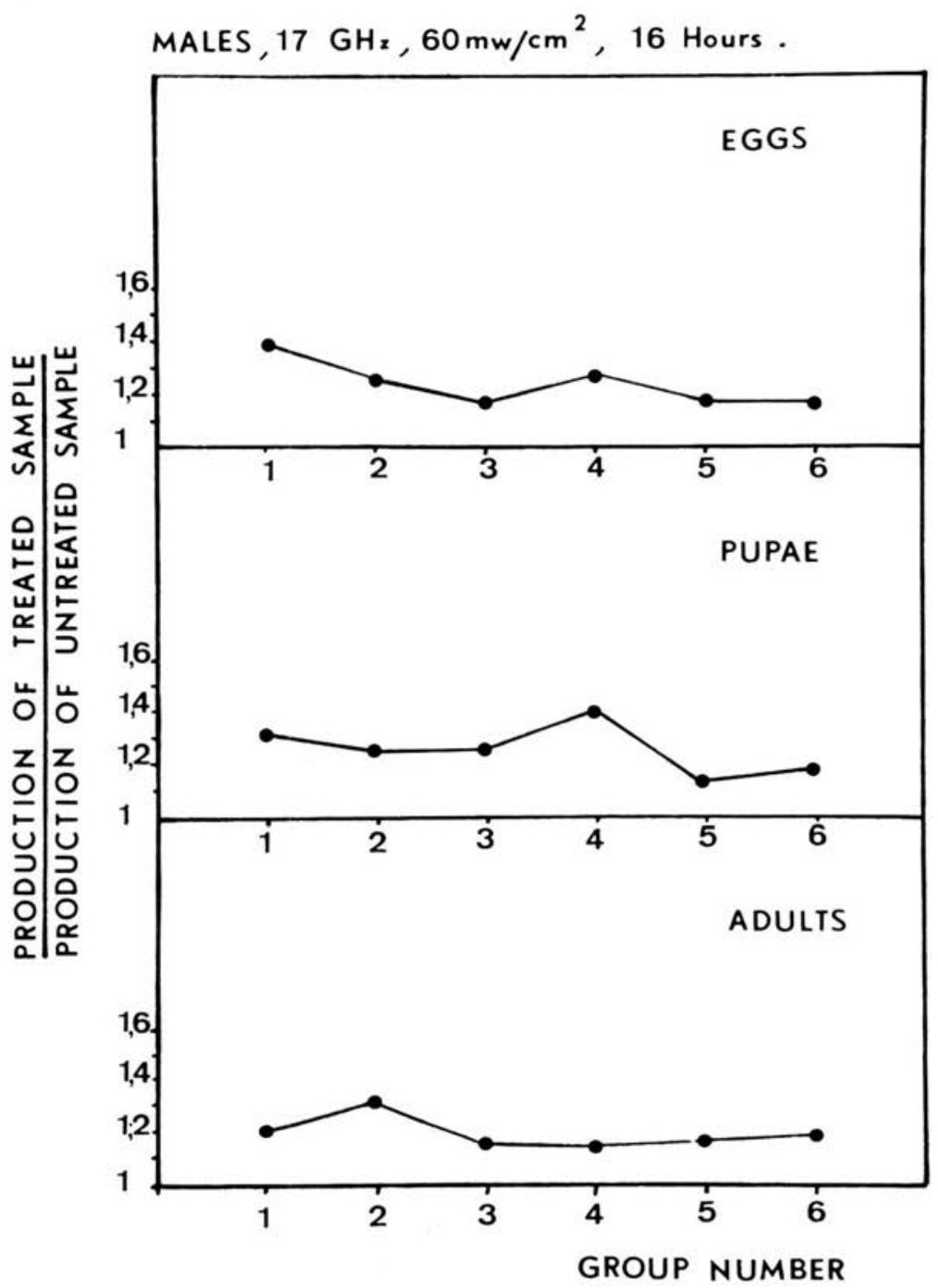

FIG. 3. - Fertility changes in females of Drosophila allowed to mate with males treated with microwaves of $17 \mathrm{GHz}$ at $60 \mathrm{~mW} \cdot \mathrm{cm}^{-2}$ for $16 \mathrm{~h}$. After mating in two day intervals, the production of eggs during 5 days and of derived pupae and adults was determined in 5 groups of females. Single experiment.

experiments. They are expressed as the ratio of the number of eggs, pupae or adults produced by the treated females versus the number of eggs, pupae or adults produced in an untreated sample.

vOL. $14-\mathrm{N}^{\circ} 3$ 
In another type of experiment ten 3-day old male flies were mated after microwave treatment with 30 untreated females which had reached maturation for 3 days. The eggs laid during $6 \mathrm{~h}$ per day were counted for up to 12 days and their development followed until the adult stage. The females (3-day old) were renewed every 2 days. As in the new females the egg production continued to be measured $6 \mathrm{~h}$ per day during 3 days in the old females which were separated from the males. The results are expressed in Figure 3 as the ratio of the number of eggs, pupae or adults produced by each group of females after mating with the microwave treated males versus the corresponding number of eggs, pupae and adults produced by females crossed with untreated males.

\section{Evaluation OF TUMORS}

After microwave treatment of the eggs, larvae and pupae of the strain $\delta$ we measured the incidence of tumors, i. e. the frequency of adult insects carrying tumors, and the multiplicity of tumors, i. e. the average number of tumors per individual adult. For the evaluation of the tumors the adult flies were analysed under a dissecting microscope (magnification $\times 23$ ).

In the strain $\delta$ the tumor incidence and multiplicity are known to be $2-3$ time higher in females than in males. However, except in Table V, we did not always separate the data for males and females (Table I-IV).

\section{Statistical anAlysis}

A detailed statistical analysis was done by F. Henry. The whole results will be published later on. A first part is already included in the present paper.

\section{RESULTS}

\section{GENERAL OBSERVATIONS}

In a first series of experiments the eggs of Drosophila melanogaster were treated at different embryonic stages with microwaves of either $17 \mathrm{GHz}$ at $60 \mathrm{~mW} . \mathrm{cm}^{-2}$ for 2 or $3 \mathrm{~h}$ or of $73 \mathrm{GHz}$ at $100 \mathrm{~mW} . \mathrm{cm}^{-2}$ for $2 \mathrm{~h}$. The development of the treated eggs was followed during 10 to 12 days and compared to that of untreated eggs.

Table I summarizes the results of two independent experiments using $17 \mathrm{GHz}$ microwaves. The number of eggs which failed to develop or which were lethal seems to be slightly enhanced after the microwave treatment of 2 and $4 \mathrm{~h}$ old eggs. The lethal eggs could be distinguished from the eggs failing to develop by their different color. Also, the development of the pupae and the adults seems to be slightly affected.

The statistical significance of this finding is indicated by the $\chi^{2}$ values. For $5 \mathrm{~h}$ old eggs, no significant differences exist between treated and untreated samples. If all results are taken together the $\chi^{2}$ values for the survival of eggs at the pupal stage relative to the control are 3.373 and for the survival of eggs up to the adult stage relative to the control 10.37. Thus, the mortality rate between the pupal and adult stage seems to be greater than between the egg and the pupal stage. As demonstrated by a statistical 


\section{TABLE I}

EFFects of microwaVes ( $17 \mathrm{GHz}, 60 \mathrm{~mW} \cdot \mathrm{cm}^{-2}, 2$ or $3 \mathrm{~h}$ ) ON Drosophila eggs TREATED AT DIFFERENT STAGES $\left(\chi^{2} \max 1.95 \%=3.84\right.$ )

\begin{tabular}{|c|c|c|c|c|c|c|}
\hline \multirow{2}{*}{ Samples } & \multicolumn{3}{|c|}{ Eggs } & \multirow{2}{*}{$\begin{array}{c}\text { Number } \\
\text { of } \\
\text { pupae }\end{array}$} & \multirow{2}{*}{$\begin{array}{c}\text { Number } \\
\text { of } \\
\text { adults }\end{array}$} & \multirow{2}{*}{$\begin{array}{l}\text { P. cent } \\
\text { adults } \\
\text { with } \\
\text { tumors }\end{array}$} \\
\hline & Total & $\begin{array}{l}\text { Failing } \\
\text { to } \\
\text { develop }\end{array}$ & Lethal & & & \\
\hline Eggs ( $2 \mathrm{~h}$ old $)$ : & & & & & & \\
\hline Untreated ...... & 440 & 13 & 1 & 426 & $322\left\{\begin{array}{l}144 \text { 우 } \\
178 \text { o }\end{array}\right.$ & 38.25 \\
\hline Treated $2 \mathrm{~h} \ldots$ & 505 & 28 & 11 & 466 & $338\left\{\begin{array}{l}165 \text { ㅇ } \\
173 \text { o }\end{array}\right.$ & 29.35 \\
\hline$\chi^{2}$ & \multicolumn{3}{|c|}{$9.16\left({ }^{*}\right)$} & $9.16\left({ }^{*}\right)$ & $4.36\left(^{*}\right)$ & $7.19(*)$ \\
\hline \multicolumn{7}{|l|}{ Eggs ( $5 \mathrm{~h}$ old $)$ : } \\
\hline Untreated ...... & 306 & 11 & 4 & 291 & $217\left\{\begin{array}{l}109 \text { 우 } \\
108 \text { क }\end{array}\right.$ & 38.5 \\
\hline Treated $2 \mathrm{~h} .$. & 320 & 16 & 3 & 301 & $207\left\{\begin{array}{r}89 \\
118 \text { o }\end{array}\right.$ & 30 \\
\hline$\chi^{2}$ & \multicolumn{3}{|c|}{0.326} & 0.326 & 2.78 & $4.00\left(^{*}\right)$ \\
\hline \multicolumn{7}{|l|}{ Eggs (4 h old): } \\
\hline Untreated ....... & 440 & 13 & 1 & 426 & $322\left\{\begin{array}{l}144 \text { 우 } \\
178 \text { 우 }\end{array}\right.$ & 38.25 \\
\hline Treated $3 \mathrm{~h} . .$. & 505 & 25 & 11 & 469 & $330\left\{\begin{array}{l}154 \text { 우 } \\
176 \text { 후 }\end{array}\right.$ & 32.5 \\
\hline$\chi^{2}$ & \multicolumn{3}{|c|}{$7.31\left(^{*}\right)$} & $7.31\left(^{*}\right)$ & $6.75\left(^{*}\right)$ & 2.66 \\
\hline
\end{tabular}

analysis of the whole survival counts the controls at the pupal and adult stage are homogeneous, and this holds also for the treated samples. Although this does not provide evidence that survival after microwave treatment depends on the developmental stage at which the insects were exposed, such a dependence cannot be totally excluded.

With regards to the number of developing adult females and males there seems to be a slight alteration of the sex ratio after the treatment of 2 or $4 \mathrm{~h}$ old eggs as compared to the controls. The development of females

VoL. $14-\mathrm{N}^{\circ} 3$ 
(or the mortality in males) appears to be favoured by the microwave treatment. As shown by the $\chi^{2}$ value, this finding is significant in two cases, for 2 and $5 \mathrm{~h}$ old eggs treated during $2 \mathrm{~h}$.

The last column of Table I includes the percentage of adults carrying tumors. There is a tendency that the number of adults with tumors is always slightly decreased in the treated sample when compared to the untreated sample. When the data on adults with tumors are summarized without considering the age of the treated eggs, the $\chi^{2}$ value is 14.42 . This demonstrates a significant difference between treated and non-treated samples, the tumor incidence being always lower in treated than in untreated samples. The multiplicity of tumors seems to be always smaller in adults derived from treated than in adults derived from untreated eggs (data not shown). No malformations could be detected in the offspring of treated eggs.

\section{TABLE II}

EFFects of Microwaves $\left(73 \mathrm{GHz}, 100 \mathrm{~mW} \cdot \mathrm{cm}^{-2}, 2 \mathrm{~h}\right.$ )

on Drosophila EGGS $\left(\chi^{2} \max , 1\right.$ degree of freedom, $95 \%=3.84$ )

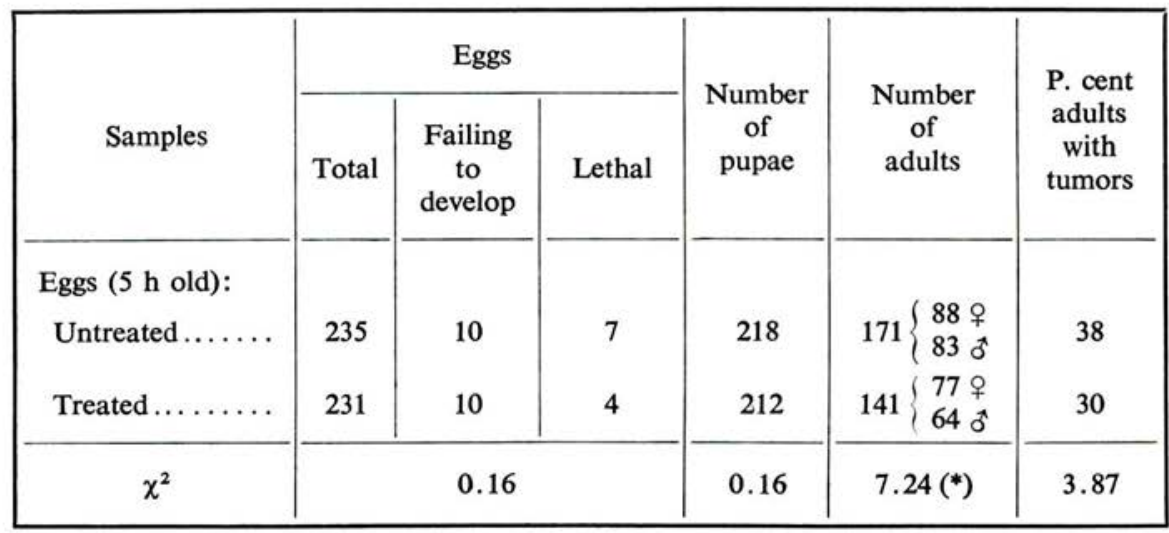

Table II shows results obtained with $5 \mathrm{~h}$ old eggs exposed to microwaves of $73 \mathrm{GHz}$ at $100 \mathrm{~mW} . \mathrm{cm}^{-2}$ for $2 \mathrm{~h}$. The statistical analysis indicates that microwaves produce a weak increase in mortality rate between the pupal and the adult stage. As with microwaves of $17 \mathrm{GHz}$ we observe a slight decrease in the incidence and multiplicity of tumors in the adults derived from treated eggs as compared to untreated eggs (data only shown for the incidence of tumors). Again we did not see any teratological changes in the offspring of treated eggs.

In order to assess further possible effects of microwaves on different developmental stages of Drosophila we treated also the larvae and the pupae. 
Table III shows the results obtained for larvae treated in the 1st, 2nd or 3rd stage of their development. The treatment involved an exposure to microwaves of $17 \mathrm{GHz}$ at $60 \mathrm{~mW} \cdot \mathrm{cm}^{-2}$ for $3 \mathrm{~h}$. The development of the larvae was followed up to the adult insect. When the results are analysed by comparing the fate of treated and untreated larvae at the subsequent pupal or adult stage no significant difference in terms of $\chi^{2}$ is seen for the pupae after a treatment of larvae in the 3rd stage and for adults after treatment of larvae in the 2nd stage. Although there seems to be a slight diminution of the tumor incidence and multiplicity of tumors in the adults derived from treated larvae when compared to the controls this is not statistically significant (only data for the incidence of tumors are shown here).

Microwave treatment of the larvae did not produce teratological changes.

TABLE III

EFFECTS OF MicrowaVES $\left(17 \mathrm{GHz}, 60 \mathrm{~mW} \cdot \mathrm{cm}^{-2}, 3 \mathrm{~h}\right)$

on Drosophila LARVAE ( $\chi^{2}$ max, 1 degree of fredom, $95 \%=3.84$ )

\begin{tabular}{|c|c|c|c|c|}
\hline Samples & $\begin{array}{c}\text { Total } \\
\text { number } \\
\text { of } \\
\text { larvae }\end{array}$ & $\begin{array}{c}\text { number } \\
\text { of } \\
\text { pupae }\end{array}$ & $\begin{array}{c}\text { number } \\
\text { of } \\
\text { adults }\end{array}$ & $\begin{array}{l}\text { P. cent } \\
\text { adults } \\
\text { with } \\
\text { tumors }\end{array}$ \\
\hline Larvae of 1st stage: & & & & \\
\hline Untreated........... & 200 & 189 & $132\left\{\begin{array}{l}61 \text { ? } \\
71 \text { o }\end{array}\right.$ & 12 \\
\hline Treated............ & 200 & 183 & $128\left\{\begin{array}{l}57 \text { \% } \\
71 \text { o }\end{array}\right.$ & 21 \\
\hline$\chi^{2}$ & - & 1.38 & 0.176 & $4.397(*)$ \\
\hline Larvae of 2 nd stage: & & & & \\
\hline Untreated......... & 200 & 174 & $153\left\{\begin{array}{l}80 \text { 우 } \\
73 \text { o }\end{array}\right.$ & 20 \\
\hline Treated........... & 200 & 172 & $135\left\{\begin{array}{l}64 \text { ㅇ } \\
71 \text { ठ }\end{array}\right.$ & 15.5 \\
\hline$\chi^{2}$ & - & 0.015 & $4.02(*)$ & 1.073 \\
\hline $\begin{array}{l}\text { Larvae of } 3 \text { rd stage: } \\
\text { Untreated ......... }\end{array}$ & 200 & 200 & $165\left\{\begin{array}{l}81 \text { o } \\
84 \text { o }\end{array}\right.$ & 14.5 \\
\hline Treated............ & 130 & 124 & $96\left\{\begin{array}{l}42 \text { ? } \\
54 \text { o }\end{array}\right.$ & 10 \\
\hline$\chi^{2}$ & - & $9.4\left(^{*}\right)$ & 3.57 & 1.168 \\
\hline
\end{tabular}

voL. $14-\mathrm{N}^{\circ} 3$ 
Table IV gives the results obtained for treated 1 and 2 day-old pupae. The treatment involved $17 \mathrm{GHz}$ microwaves at a power density of $60 \mathrm{~mW} . \mathrm{cm}^{-2}$ during $2 \mathrm{~h}$. The development of treated and untreated pupae is not statistically different. The survivals, sex ratios and incidence of tumors of the adult insects are comparable in treated and untreated samples. The multiplicity of tumors in the adults derived from treated pupae is slightly decreased in comparison to the control. Again we did not see any malformation in the adults.

\section{TABLE IV}

EFFects of Microwaves $\left(17 \mathrm{GHz}, 60 \mathrm{~mW} \cdot \mathrm{cm}^{-2}, 2 \mathrm{~h}\right)$ ON Drosophila PUPAE TREATED AT DIFFERENT STAGES $\left(\chi^{2} \max , 1\right.$ degree of freedom, $\left.95 \%=3.84\right)$

\begin{tabular}{|c|c|c|c|}
\hline Samples & $\begin{array}{c}\text { Total } \\
\text { number } \\
\text { of } \\
\text { pupae }\end{array}$ & $\begin{array}{c}\text { number } \\
\text { of } \\
\text { adults }\end{array}$ & $\begin{array}{c}\text { P. cent } \\
\text { adults } \\
\text { with } \\
\text { tumors }\end{array}$ \\
\hline Pupae (1 day old): & & & \\
\hline Untreated ............ & 200 & $165\left\{\begin{array}{l}81 \text { 우 } \\
84 \text { o }\end{array}\right.$ & 14 \\
\hline Treated.............. & 136 & $109\left\{\begin{array}{l}48 \text { ? } \\
61 \text { t }\end{array}\right.$ & 10 \\
\hline$\chi^{2}$ & - & 0.30 & 1.17 \\
\hline Pupae ( 2 days old): & & & \\
\hline Untreated...$\ldots \ldots \ldots$ & 558 & $416\left\{\begin{array}{l}190 \% \\
226 \text { o }\end{array}\right.$ & 25 \\
\hline Treated ............. & 490 & $349\left\{\begin{array}{l}163 \text { 우 } \\
186 \text { o }\end{array}\right.$ & 23.78 \\
\hline$\chi^{2}$ & - & 1.465 & 0.135 \\
\hline
\end{tabular}

\section{INCIDENCE AND MULTIPLICITY OF TUMORS IN THE ADULTS OF THE TUMORIGENIC} STRAIN $\delta$

It was especially interesting to see whether microwaves could interfere with the development of tumors in the highly tumorigenic Drosophila strain $\delta$. Table V summarizes the results obtained for irradiated eggs, larvae and pupae. There is a high incidence of tumors in controls. After microwave treatment the number of adults carrying tumors decreases independently from the embryonic stage in which the irradiation was done. This slight 
decrease is similar for adults derived from eggs treated with 17 or $73 \mathrm{GHz}$ microwaves.

\section{TABLE V}

EFFects OF Microwaves $\left(17 \mathrm{GHz}, 60 \mathrm{~mW} . \mathrm{cm}^{-2}, 2-3 \mathrm{~h}\right.$ ) ON TUMOR DEVELOPMENT IN THE Drosophila STRAIN $\delta$ TREATED AT DIFFERENT STAGES

\begin{tabular}{|c|c|c|c|c|}
\hline & ples & $\begin{array}{c}\text { Total number } \\
\text { of developped } \\
\text { adults }\end{array}$ & $\begin{array}{c}\text { Number } \\
\text { of adults } \\
\text { with tumors }\end{array}$ & $\begin{array}{l}\text { Average } \\
\text { multiplicity } \\
\text { of tumors }\end{array}$ \\
\hline Eggs & $\begin{array}{l}\mathrm{U} \ldots \ldots \\
\mathrm{T} \ldots \ldots \\
\mathrm{U} \ldots \ldots \\
\mathrm{T} \ldots \ldots\end{array}$ & $\begin{array}{l}522 \text { o } \\
536 \text { क } \\
600 \text { o } \\
577 \text { o }\end{array}$ & $\begin{array}{r}336 \text { ㅇ } \\
286 \text { ㅇ } \\
141 \text { o } \\
69 \text { o }\end{array}$ & $\begin{array}{l}0.946 \pm 0.011 \\
0.736 \pm 0.014 \\
0.306 \pm 0.032 \\
0.164 \pm 0.036\end{array}$ \\
\hline Larvae & $\begin{array}{l}\mathrm{U} \ldots \ldots \\
\mathrm{T} \ldots \ldots \\
\mathrm{U} \ldots \ldots \\
\mathrm{T} \ldots \ldots\end{array}$ & $\begin{array}{l}160 \text { क } \\
149 \text { क } \\
168 \text { o } \\
150 \text { o }\end{array}$ & $\begin{array}{rl}107 & \uparrow \\
82 & + \\
49 & 0 \\
25 & 0\end{array}$ & $\begin{array}{l}0.887 \pm 0.358 \\
0.758 \pm 0.0487 \\
0.375 \pm 0.091 \\
0.21 \pm 0.18\end{array}$ \\
\hline Pupae & $\begin{array}{l}\mathrm{U} \ldots \ldots \\
\mathrm{T} \ldots \ldots \\
\mathrm{U} \ldots \ldots \\
\mathrm{T} \ldots \ldots\end{array}$ & $\begin{array}{l}253 \text { ㅇ } \\
211 \text { ㅇ } \\
294 \text { o } \\
245 \text { o }\end{array}$ & $\begin{array}{r}162 \text { ㅇ } \\
75 \text { ㅇ } \\
64 \text { o } \\
19 \text { o }\end{array}$ & $\begin{array}{l}0.853 \pm 0.023 \\
0.431 \pm 0.058 \\
0.278 \pm 0.072 \\
0.085 \pm 0.257\end{array}$ \\
\hline
\end{tabular}

$\mathrm{U}$, untreated; $\mathrm{T}$, treated.

Analysis of tumor incidence in all the males and females shows that it is always about $10 \mathrm{p}$. cent lower in treated samples than in untreated samples. Individual adult insects can carry up to 5 tumors the distribution of which follows a Poisson distribution. Considering the average multiplicity of tumors in the adults it becomes clear that in all cases microwave treatment has modified the multiplicity of tumors. And this does not seem to depend on the sex.

\section{FERTILITY OF ADULT INSECTS AFTER MICROWAVE EXPOSURE}

The effect of open space microwave irradiation on the fertility of the adult insects was also tested, using the same methods.

Figure 2 shows the results obtained when adult females were exposed to microwaves of $17 \mathrm{GHz}$ at $60 \mathrm{~mW} . \mathrm{cm}^{-2}$ during $16 \mathrm{~h}$ and then mated with untreated males. The results are derived from 3 independent experiments. Another experiment in which the females were exposed during $21 \mathrm{~h}$ gave the same results. The upper part of Figure 2 shows egg production of treated females versus that of untreated females as a function of the time

voL. $14-\mathrm{N}^{\circ} 3$ 
of oogenesis. The development of the laid eggs was followed up to the stage of the pupae (middle part) and of the adults (lower part).

In spite of large daily variations which can differ from experiment to experiment, egg production, i. e. the fertility of females exposed to microwaves, was on average $30 \mathrm{p}$. cent higher than that of untreated females. In other words, the ratio of the eggs produced by the treated versus those produced by untreated females is about 1.3. This increase in fertility is statistically highly significant. It is a long lasting phenomenon, still evident 10 to 12 days after the microwave treatment.

Comparable increases with sometimes important daily variations were observed in the produced offspring (pupae and adults). The increased number of eggs produced by treated females is accompanied by an increase of the derived pupae and adults.

Statistical analysis seems to indicate that this phenomenon may be related to the different stages of oogenesis at which cells have been treated that participate in the formation of eggs in the females. Certainly in some experiments such a relation exists; however, this is not evident when average values are considered. Since the viability of eggs produced by the two different groups does not decrease, the observed effect cannot be explained by assuming a change of viability of the eggs produced by treated females as compared to untreated females.

Under the dissecting microscope no malformations were observed in the adult insects.

Statistical analysis in series brought about no difference in the number of females derived from treated and untreated females. In contrast, the number of derived male insects is significantly higher in the treated sample than in the control. This increase may be explained by a viability rise of eggs leading to the development of male insects.

Also, when analysing the results of the pupae it appears that survival in that stage is always better in the treated than in the untreated sample.

In order to see whether the observed microwave effects depend on the mating type of the adult irradiated we also performed experiments in which the male flies were exposed to microwaves before being allowed to mate with untreated females.

Figure 3 shows the results obtained including data for egg-production, pupae and adults. The number of eggs produced by the females which were mated with microwave treated males is on average $20 \mathrm{p}$. cent higher than in controls. Again, this increase in fertility seems to be a long-lasting effect; it is observed in 5 different groups of females and it persists for up to 10 to 12 days after treatment of the males. The viability of the eggs produced in the treated samples is the same as in controls: the increase of pupae and adults is parallel to the increase in egg production.

As in the case of microwave treated females, we did not observe any malformations in the offspring (adults) when the males were irradiated. 


\section{DISCUSSION AND CONCLUSION}

The results demonstrate a weak effect of 73 and $17 \mathrm{GHz}$ microwaves on the survival of Drosophila eggs, larvae or pupae. In certain experiments the effect is statistically significant, in others it is not. However, when the effect is significant it is always towards a diminution of the survival of the irradiated sample. The adult flies derived from irradiated eggs, larvae or pupae show no teratological changes. After microwave treatment we also noticed a diminution in the incidence and multiplicity of tumors. This decrease is not always statistically significant. It seems to be independent of the embryonic, larvae and pupal stages at which treatment was performed. Microwaves frequency does not seem to be important since the slight decrease of tumors can be observed after treatment with microwaves of either $17 \mathrm{GHz}$ at $60 \mathrm{~mW} \cdot \mathrm{cm}^{-2}$ during $2 \mathrm{~h}$ or $73 \mathrm{GHz}$ at $100 \mathrm{~mW} \cdot \mathrm{cm}^{-2}$ during $2 \mathrm{~h}$. This weak action of microwaves on tumorigenesis in Drosophila clearly differs from that of ionizing irradiation which is known to increase at the same time the incidence and multiplicity of tumors [6,9].

The genetic control of the melanitic tumors in Drosophila is complex. Tumor development depends on the presence of several main gene products which can be modified by other genes. Therefore, the microwave treatment may decrease the probability of tumoral transformations of cells to occur by changing the expression of a tumoral gene, in other words, microwaves seem to react with the cellular constituents in charge of the transformation. It is known that particularly microwaves in the millimeter range can also act at the molecular level $[10,11]$. Since the cytoplasm plays an important role for the expression and manifestation of the tumoral character [7], it is also possible that microwaves exert their action by modifying the state of the cytoplasm and by impairing the activity of the tumoral gene. Of course, we cannot totally exclude that the weak effect of microwaves on tumorigenesis may be due to thermic effects. However, this seems unlikely. In larvae exposed to a temperature of 29 or $30^{\circ} \mathrm{C}$ tumor development is completely suppressed in a fraction of adults without any change in the multiplicity of tumors in the other fraction of adults [12].

In contrast, microwaves always produced a tendency for a decreased incidence and a decreased multiplicity of tumors at the same time. After treatment of adult males and females during $16 \mathrm{~h}$ with microwaves of $17 \mathrm{GHz}$ at $60 \mathrm{~mW} \cdot \mathrm{cm}^{-2}$ we observed an increase of fertility which could be seen by measuring the production of eggs after mating. The viability of the eggs derived from treated adults was always similar and sometimes even better than in controls. There was not one single case for which change in fertility was accompanied by a teratological change in the offspring of the first generation.

In conclusion, it can be said that from the results obtained with open space $17 \mathrm{GHz}$ microwave irradiation of Drosophila at different developmental stages for 2,3 or $16 \mathrm{~h}$ strikingly differ from those obtained with Tenebrio molitor in the waveguide with microwave irradiation of $9 \mathrm{GHz}$ at $20 \mathrm{~mW} \cdot \mathrm{cm}^{-2}$.

voL. $14-\mathrm{N}^{\circ} 3$ 
Our results on the survival at different embryonic stages, larvae and pupae of Drosophila and the fertility of treated adult flies agree with those of Russian authors who demonstrated that a 15 to 60 min irradiation of males and females of Drosophila produced no lethal effects, the insects showed no obvious malformations and had normal offspring. However, after treatment with millimeter waves the offspring was smaller in number and fertility was modified according to radiation frequency and exposure time [3]. The increased fertility observed under our irradiation conditions (centimeter waves) may be explained by the assumption that microwaves can interfere with the metabolism of hormones as stated for higher animals [13-17].

\section{AKNOWLEDGEMENTS}

We wish to thank Dr. S. GHeleLovitCH and Miss C. Baroche for their kind introduction into the work with Drosophila and for their help in providing the strains, laboratory material and technical advice. We are grateful to Dr. R. LATARJET for his interest in our work.

This work was supported by the D.R.E.T. France, contract 76/1157. We are indebted to Dr. G. Plurien and Dr J. Doucet who greatly encouraged this work.

\section{REFERENCES}

[1] Carpenter R. L., Livstone E. M., Evidence for non thermal effects of microwave radiation: abnormal development of irradiated insect pupae. IEEE Trans. MTT, 1971, 19, 173-178.

[2] Lindauer G. A., Liu L. M., Skewes G. W., Rosenbaum F. J., Further experiments seeking evidence of non thermal biological effects of microwave radiation. IEEE Trans. MTT, 1974, 22, 790-793.

[3] Zalyubovskaya N. P. Reactions of living organisms to exposure to millimeter band electromagnetic waves, Scient. Session of Division of gen. Phys. and Astron. U.S.S.R. Acad. Sc., Jan. 17-18 1973, Sov. Phys. Usp., 1974, 16 (4), 568-579.

[4] МікотаЈсZук H. Microwave induced shifts of gonadotropic activity in anterior pituitary gland of rats. In: Biological effects of electromagnetic waves, selected papers of the U.S.N.C./U.R.S.I. Annual Meeting, Boulder, 20-23 Oct. 1975 (C. C. JoHnson, M. L. Shone, Eds.), H.E.W. Publications (F.D.A.) 77-8010, 1977, 1, 377-383.

[5] Berteaud A. J., Dardalhon M., Rebeyrotte N., Averbeck D. Action d'un rayonnement électromagnétique à longueur d'onde millimétrique sur la croissance bactérienne. C. R. Acad. Sc., Paris, 1975, 281, série D, 843-846.

[6] Ghelelovitch S. Influence des rayons X sur le développement des tumeurs mélaniques chez la drosophile. Biol. Med., 1973, 48, 151-173.

[7] Ghelelovitch S. Tumeurs mélaniques héréditaires de la drosophile. Déterminisme de la transformation tumorale des hémocytes de la larve. C. R. Soc. Biol., 1975, 169, 788-795.

[8] Ghelelovitch S. Restauration des lésions provoquées par les rayons $\mathrm{X}$ chez les embryons de la drosophile (D. melanogaster Meig.). Int. J. Radiat. Biol., 1974, 27, 513-523.

[9] Hartung E. W. The effects of Roentgen radiation on tumor incidence in Drosophila melanogaster. Cancer Res., 1942, 2, 837-840. 
[10] Illinger K. H. Interaction between millimeter wave electromagnetic fields and biological systems. In: Molecular mechanisms, biological effects and health hazards of microwave radiation. Int. Symp., Warsaw, Polish Medical Publishers, 1974, 160-172.

[11] FröLich H. Evidence for Bose condensation-like excitation of coherent modes in biological systems. Phys. Letters, 1975, 51 A, (1), 21.

[12] Ghelelovitch S. Une tumeur héréditaire de la drosophile. Biol. Med., 1958, 47, 711-810.

[13] Baranski S., OstrowsKi K., StodolniK W. Experimental investigations on the influence of microwaves on thyroid function. Acta Phys. Polon., 1973, 43, 608.

[14] Deschaux P., Pelissier J. P. Effect of microwaves on steroids plasma levels in male rats. J. Microwave Power, 1977, 12, 1.

[15] Gunn S. A., Gould T. C., Anderson W. A. D. The effect of microwave radiation on morphology and function of rat testis. Lab. Invest., 1961, 10, 301.

[16] Deficis A., Dumas J. C., Laurens S., Plurien G. Variation of serum triglycerides rate under the action of electromagnetic waves: power level influence. J. Microwave Power, 1976, 11, 136-137.

[17] Deficis A., Dumas J. C., Laurens S., Plurien G. Effect of electromagnetic energy on the formation of triglycerides: frequency influence. J. Microwave Power, 1976, 11, 137-138. 